\title{
Da cozinha à sala de estar: um olhar sobre a gastronomia no jornalismo cultural brasileiro
}

\author{
Renata Maria do Amaral1 \\ Universidade Federal de Pernambuco \\ reamaral@gmail.com
}

\begin{abstract}
Resumo: Destinado a apresentar os resultados da dissertação de mestrado "Gastronomia: prato do dia do jornalismo cultural", este artigo apresenta um mapeamento do jornalismo gastronômico, inserido no contexto do jornalismo cultural brasileiro contemporâneo. Optamos por centrar a análise nos gêneros crítica e crônica, por serem bastante freqüentes no jornalismo cultural, em quatro veículos de circulação nacional. Observamos que as crônicas apresentaram duas características comuns aos veículos Claudia Cozinha e Carta Capital: a interatividade e a narrativa. Verificamos que a crônica se caracteriza como um espaço da subjetividade, em que o narrador busca interagir com o leitor. Já as críticas não apresentaram estratégias comuns à Folha de S.Paulo e à Gula, exceto pela titulação descritiva. As críticas são exemplos do jornalismo de serviço, que oferece informações para usufruto do leitor.
\end{abstract}

Palavras-chave: jornalismo gastronômico; jornalismo cultural; gêneros jornalísticos

\begin{abstract}
This article aims to present the results of the dissertation "Gastronomy: cultural journalism today's special", in which we started a mapping of gastronomical journalism into the context of Brazilian contemporary cultural journalism. We studied four publications and decided to focus the investigation in review and chronicle genres, as they are very usual in cultural journalism. We noticed that both chronicles sections in Claudia Cozinha and Carta Capital had two properties in common: interaction and narrative structure. Chronicles are distinguished as a place of subjectivity, where the narrator interacts with the reader and tries to start a dialogue with him. The reviews did not present strategies shared by Folha de S.Paulo and Gula, except for descriptive titles. Critics are part of what is called service journalism, in which the writer offers information that can be actually used by the readers.
\end{abstract}

Keywords: gastronomical journalism; cultural journalism; journalistic genres

${ }^{1}$ Mestre em Comunicação pela UFPE. 
Résumé: Destiné à présenter les résultats de la dissertation du mastère "Gastronomie: plat du jour du journalisme culturel", cet article présente un aperçu du journalisme gastronomique inséré dans le contexte du journalisme culturel brésilien contemporain. Nous avons opté pour centrer notre analyse dans les genres critique et chronique, puisqu'ils sont assez fréquents dans le journalisme culturel, dans quatre véhicules de circulation nationale. Nous avons observé que les chroniques ont présenté deux caractéristiques communes aux véhicules Claudia Cozinha et Carta Capital: l'interactivité et la narrative. Nous avons vérifié que la chronique est caractérisée comme un espace pour la subjectivité, où le narrateur cherche à interagir avec le lecteur. Par contre, les critiques n'ont pas présenté de stratégies communes dans le journal Folha de S.Paulo et dans le magazine Gula, sauf pour les titres descriptifs. Les critiques sont des exemples de journalisme de service qui offre des informations pour l'usufruit du lecteur.

Mots clés: journalisme gastronomique; journalisme culturel; genres journalistiques

Resumen: Este artículo presenta los resultados de la tesina de máster "Gastronomía: plato del día del periodismo cultural", que trae un panorama del periodismo gastronómico en el contexto del periodismo cultural brasileño contemporáneo. Decidimos analizar los géneros crítica y crónica, que son muy frecuentes en el periodismo cultural, en cuatro publicaciones nacionales. Verificamos que las crónicas tienen dos puntos comunes a los magazines Claudia Cozinha e Carta Capital: la interactividad e la narración. La crónica surge como un hogar de la subjetividad, en que el narrador intenta interaccionar con el lector. Las críticas, por su turno, solo tuvieron como estrategia común al periódico Folha de S.Paulo e al magazine Gula la titulación descriptiva. Las críticas son ejemplos del periodismo de servicio, cuyas informaciones son efectivamente utilizadas por los lectores.

Palabras clave: periodismo de gastronomía; periodismo cultural; géneros de periodismo 


\section{Introdução}

O jornalismo gastronômico é um dos temas do jornalismo cultural que mais vem crescendo no Brasil, juntamente com a importância da própria gastronomia. O assunto deixou de ser periférico para se tornar comum em jornais e revistas. Em vez de freqüentar apenas as seções de receitas das publicações femininas, como antigamente, a gastronomia agora figura como assunto recorrente em publicações de todos os tipos, voltadas para públicos variados. Nosso objetivo principal com este artigo, que resume os resultados da pesquisa de mestrado "Gastronomia: prato do dia do jornalismo cultural", é apresentar um mapeamento do jornalismo gastronômico, inserido no contexto do jornalismo cultural brasileiro contemporâneo. Partimos da observação de que a crescente importância desse tema na imprensa constitui um fenômeno que se dá paralelamente a uma valorização do assunto na sociedade em geral.

Optamos por centrar a análise nos gêneros crítica e crônica, por serem bastante presentes no jornalismo cultural. Em seguida, demos início à coleta de dados, que compreendeu todo o material publicado durante o ano de 2004 nas seções de crítica "Gula Indica Restaurantes" (Revista Gula) e "Mundo Gourmet" (Folha de S.Paulo) e de crônica "Pé na Cozinha" (Claudia Cozinha) e "Refogado" (Carta Capital), num total de 145 textos. Como nossa intenção era dar início à exploração sobre o tema, optamos por selecionar publicações bem diversas para análise. Duas delas são revistas especializadas no assunto: enquanto a Gula tem um perfil refinado, a Claudia Cozinha apresenta matérias e receitas mais cotidianas, mas vale ressaltar que esse direcionamento vem mudando e que a revista está procurando se adequar para atender também ao público gourmet. Os outros dois objetos do corpus não tratam somente de gastronomia - pelo contrário, são veículos de temática ampla que discorrem sobre o tema na seção cultural. O jornal Folha de S.Paulo vem aumentando o espaço para o assunto em suas páginas: durante os dois anos de nossa exploração, a seção dedicada ao tema quadruplicou de tamanho. Já a revista Carta Capital apresenta uma coluna fixa de crônicas sobre gastronomia. 
Um ponto essencial deve ser frisado: o critério que utilizamos para escolher os dois veículos cujas críticas analisamos aqui - o jornal Folha de S.Paulo e a revista Gula - foi a garantia do anonimato dos jornalistas. Em ambas as empresas, os críticos freqüentam os restaurantes avaliados sem se identificar e pagam sua conta, como qualquer cliente. Essa atitude pode parecer um detalhe insignificante, mas na verdade garante ao crítico liberdade e certeza de que não será tratado de forma diferenciada por estar avaliando o estabelecimento. É comum, em outros jornais e revistas, que os jornalistas visitem restaurantes após serem convidados, sendo inclusive recebidos pelos donos dos estabelecimentos ou pelos chefs de cozinha. Em geral, tais convites são intermediados por assessorias de imprensa, que ajudam a promover a imagem dos seus clientes.

Depois de selecionadas as críticas e crônicas, partimos para a leitura do corpus e a escolha do arcabouço teórico. Todos os textos foram lidos atentamente em busca de seus aspectos recorrentes. Nossa aposta era que esses aspectos, por sua vez, seriam os indicadores das principais características dos dois gêneros no campo da gastronomia. Essa "decupagem" inicial resultou numa lista de seis categorias lingüístico-discursivas que passaram a direcionar nosso olhar analítico sobre o corpus textual. Essas categorias são as seguintes: narrativa, titulação, interatividade, intertextualidade, ironia e metáfora. Como algumas delas são estudadas preferencialmente pela Lingüística Textual, outras pela Lingüística Cognitiva, outras pela Pragmática, outras ainda pela Análise do Discurso, decidimos não restringir o aparato teórico de análise a uma só corrente teórica, optando por utilizar teorias que a nosso ver melhor serviriam para abordar o objeto de pesquisa.

Após a delimitação das categorias teóricas que orientam o nosso estudo, selecionamos, levando em consideração a divisão dos textos por gênero e por veículo, exemplos significativos para compor a análise. É importante frisar que utilizamos o critério da predominância, ou seja, a freqüência com que as categorias aparecem em cada gênero e veículo, no intuito de apreender quais as características mais marcantes das críticas e crônicas e, assim, ter um mapeamento de como se configura o texto do jornalismo gastronômico. Antes de efetuar o estudo dos textos propriamente ditos, realizamos uma breve discussão sobre cada um dos veículos, a partir da bibliografia consultada e de entrevistas com críticos, cronistas e editores. 


\section{A crítica e a crônica no jornalismo cultural}

Acreditamos que é importante deixar claros os conceitos de crítica e crônica que utilizamos. Quais as características da crítica como gênero? A crítica é o gênero jornalístico opinativo que analisa e avalia trabalho intelectual ou desempenho (Novo Manual da Redação, 1992). Sempre traz a assinatura de seu autor e deve ser bem fundamentada. Além disso, não deve conter acusação de ordem pessoal. Lembre-se: o objeto da crítica é a obra ou desempenho, não a pessoa (Novo Manual da Redação, 1992:66).

Seria a gastronomia um objeto digno de ser criticado? Para responder a essa pergunta, recorremos à introdução de Philip French à coletânea de críticas de cinema de Pauline Kael, que ajudou a mudar a natureza e o status da crítica de cinema no mundo de língua inglesa. Transformou-a em uma atividade emocionante, vital e essencial, um diálogo com nossa época e cultura (French, 2000:13). Quando Kael começou a publicar suas análises em jornais, o cinema era tido como uma arte menor e só então começava a ser objeto de apreciação crítica:

Naquela noite, fizeram-se as perguntas de sempre sobre a função da crítica e a responsabilidade do crítico, embora provavelmente fosse a última vez que alguém em Nova York perguntou se a crítica de cinema podia ser uma atividade tão importante quanto a de outras artes (French, 2000:12).

O papel da crítica na consolidação dos produtos culturais é destacado por Melo (2003), que verifica a relação entre fontes de receita publicitária e a ação dos jornalistas dos suplementos:

Seu [da crítica] âmbito de ação contempla os produtores tradicionais, como a literatura e o livro, a música e as artes plásticas, o teatro e a dança, mas atribui ênfase aos novos produtos da indústria cultural que constituem fonte segura de receita publicitária: a televisão, o cinema, a música, e até mesmo o esporte, a gastronomia e a publicidade (grifos nossos) (Melo, 2003:138).

A crônica é o segundo gênero que analisaremos dentro do jornalismo cultural sobre gastronomia. Sua definição varia de país para país - no Brasil, toma ares de relato poético do real, situado na fronteira entre a informação de atualidade e a narração literária (Melo, 2003:155), enquanto na maior parte do mundo se caracteriza como um relato cronológico. Aqui, os fatos são apenas um mote ou pretexto. A crônica se caracteriza pela ligação com o cotidiano e a crítica social 
dissimulada nos meandros da poeticidade do texto. A informalidade e a despretensão podem esconder críticas severas:

Se a crônica de costume se valia do real (fatos ou idéias do momento) simplesmente como "deixa" ou como inspiração para um relato poético ou para uma descrição literária, a crônica moderna assume a palpitação e a agilidade de um jornalismo em mutação. Ele figura no corpo do jornal não como objeto estranho, mas como matéria inteiramente ligada ao espírito da edição noticiosa (Melo, 2003:155).

Para Melo (2002), a crônica se aproxima da literatura, mas não alcança o nível de um romance ou uma poesia. Com isso, o autor não quer depreciar o gênero, mas ressaltar suas peculiaridades, como a simplicidade, a efemeridade e o tom audacioso. Outro fator que influi para o maior cuidado na elaboração das crônicas é que os cronistas são considerados "colaboradores" em relação aos profissionais da redação. Normalmente não freqüentam a sala de redação; enviam seus textos (Guaraciaba, 1992:87). Não cabe ao cronista entrevistar nenhum "personagem”, mas observar anonimamente e expor suas impressões.

Na relação íntima e companheira que estabelece com o leitor, o cronista acaba ganhando ares de amigo. Em certos momentos, principalmente neste mundo de solitários em que vivemos, o cronista periga de se tornar quase alguém da família. Ou, se bobear, um amante (Menezes, 2002:168). Descontados os exageros, é certo que ler uma crônica em meio a inúmeras notícias dá um toque de sabor à apreciação diária do jornal. Para continuar nas metáforas gastronômicas, fechamos esta seção citando Galeno (2002):

Texto e sabor são ingredientes que deverão constar na mesa de todos. Ser diário não significa estar preso ao presente e à mera reprodução enfadonha dos dias. Mesmo que a origem da palavra jornal, do latim diurnalis (diário) se relacione ao cotidiano, ao contar dos dias, ao narrar dos acontecimentos (Galeno, 2002:107108).

\section{A crônica no jornalismo gastronômico}

Como dissemos anteriormente, optamos por estudar separadamente crônicas e críticas sobre gastronomia a fim de melhor analisar suas características particulares. Além disso, procuramos observar as estratégias mais utilizadas por cada um dos quatro veículos do corpus separadamente. 
$\mathrm{Na}$ análise das crônicas, encontramos como características lingüísticodiscursivas comuns aos dois veículos em questão - Claudia Cozinha e Carta Capital a interatividade e a narrativa. Ambas as características são fortemente relacionadas ao tom subjetivo e intimista desse gênero textual: a interatividade sugere um diálogo com o leitor e a narrativa é o tipo textual mais usado por quem deseja contar histórias. Tais categorias apontam para a crônica como um espaço da subjetividade. Ao lado desses recursos presentes nos dois veículos, encontramos outros peculiares a cada revista. Na seção "Refogado", da Carta Capital, a ironia é a característica mais marcante do conjunto de textos. Já na seção "Pé na Cozinha", da Claudia Cozinha, a cronista lança mão da intertextualidade como inspiração para contar suas histórias.

Para compreender melhor a escolha por tais recursos, é importante abordar a história de cada uma das revistas. A Claudia Cozinha é filha da revista Claudia, que está no mercado de publicações femininas desde 1961. Teve início como um suplemento encartado em 1965, com o nome de Jornal da Cozinha, e virou uma revista independente em 2000. A Claudia Cozinha já teve circulação mensal, em seguida bimestral e, no período de realização desta pesquisa, voltou a chegar às bancas todos os meses. Em todo esse tempo, muita coisa mudou. É possível acompanhar a evolução do perfil da revista Claudia Cozinha por seus slogans mais recentes, publicados logo abaixo do título da publicação: de "A única revista brasileira que testa todas as receitas em sua cozinha experimental", em 2000, e do semelhante, mas algo simplificado, "Todas as receitas testadas e com fotos", em 2004, ao novo "O prazer da gastronomia na sua vida", em 2005, a Claudia Cozinha parece estar ampliando seu público. Na última reforma gráfica e editorial, incluiu indicações de vinhos para todas as receitas, o que indica um refinamento da antiga leitora interessada apenas em prendas domésticas. As portas estão também mais abertas ao público masculino - basta observar que se procura não mais usar a expressão "leitora", no feminino.

Perfil bem diverso da Carta Capital. Mais conhecida pela abordagem crítica de temas políticos e econômicos, a revista publica em todas as suas edições uma seção de crônicas sobre gastronomia chamada "Refogado", a cargo do cronista e publicitário Marcio Alemão. Publicada pela Editora Confiança, a revista tem periodicidade semanal e foi fundada em 1994 pelo jornalista italiano Mino Carta, que 
havia passado por revistas como Veja e IstoÉ e tinha como meta criar um semanário crítico e independente.

Passemos, agora, a tratar da categoria da narrativa. Convencionalmente, esse tipo textual contém os seguintes momentos: exposição, introdução ou apresentação (apresentação dos fatos e personagens), complicação ou desenvolvimento (trecho em que se desenvolve o conflito e se conquista a atenção do leitor), clímax (ponto máximo do conflito) e desfecho, desenlace ou conclusão (solução dos conflitos, de forma boa ou má). Gancho (1997) considera que as crônicas, por serem textos híbridos entre a literatura e o jornalismo, não raro apresentam narrativa incompleta.

Gomes (1994) considera que os textos jornalísticos se baseiam em relatos com fatos hierarquicamente ordenados. A narrativa, assim, está cada vez mais presente nos meios de comunicação como maneira de atrair o leitor. A autora especifica de que forma a clássica estrutura da narrativa proposta por Labov e Waletzky (ver referências complementares) se apresenta no jornalismo: o resumo seria composto pelos títulos e subtítulos, a orientação equivaleria ao lide, a complicação abrangeria o fato propriamente dito, a avaliação seria marcada pelo ponto de vista do narrador e a resolução seria o desfecho da história (considerada rara no jornalismo, porque em geral as histórias se encontram em andamento). As partes da narrativa, no entanto, podem vir imbricadas e às vezes são difíceis de identificar com clareza.

Exemplifiquemos a narrativa na crônica "Comida de cachorro", publicada na edição de março/abril da Claudia Cozinha. Observemos o seguinte trecho:

Agora os cachorros comem ração e parece que gostam. Há anos comiam o músculo da sopa. Eu me lembro de ir ao Rio passar as férias na casa de uma tia chique. Na época o prato da moda eram metades de chuchu recheadas com passas. E um dia não é que a tia me pegou, depois de recusar a iguaria, salivando, de olho na comida do Rex?

É pela divertida história de quando a narradora, ainda garota, tinha inveja da comida do cachorro de sua tia rica que a cronista compõe o texto para falar que o músculo bovino está em voga nas grandes cozinhas hoje. A narrativa é parte essencial das crônicas, uma vez que podem remeter a situações na vida cotidiana para 
comentar fatos da atualidade - como o lançamento do livro de um chef sobre músculo, nesse exemplo. Aqui, a estrutura narrativa cumpre o papel de transportar o leitor para a infância da narradora, ajudando-o a compreender porque ela dá tanta importância à iguaria.

Já na Carta Capital, notamos que a narrativa, em geral irônica, freqüentemente culmina em uma espécie de moral da história, ou seja, em um recurso que apresenta uma posição mais séria, em oposição ao restante do texto, baseado no humor calcado na ironia.

Outra característica marcante das crônicas analisadas é a interatividade. Durante muito tempo, esse aspecto foi estudado como um fenômeno exclusivo da fala. No entanto, deve ficar claro que a interatividade é uma propriedade geral de todo e qualquer uso da língua e não de uma das modalidades de uso. Pois ninguém escreve/fala sem ter em mente um leitor/ouvinte (Marcuschi, 1999:2). Não estamos falando, então, de marcas de oralidade, mas de indícios de destinação de um texto escrito/falado a um leitor/ouvinte real ou imaginário.

Tannen (1989) enfatiza que não existe interação sem envolvimento. Para tanto, relaciona o segundo termo a uma linha de pesquisa voltada para a conversação como produção compartilhada. Estratégias de envolvimento constituem regularidades evidenciadas na configuração das formas de expressão utilizadas pelo sujeito tanto na modalidade oral quanto na escrita. A idéia de envolvimento foi proposta inicialmente por Chafe (1985), que o classificou em três tipos: envolvimento do falante consigo mesmo ou auto-envolvimento (evidenciado pela presença de pronomes de primeira pessoa e possessivos correspondentes e referências à comunicação do processo mental do falante), envolvimento do falante com o ouvinte (ocorre mediante o emprego de pronomes de segunda pessoa, citação do nome do ouvinte, respostas a questões formuladas pelo interlocutor, uso de marcadores conversacionais e expressões formulaicas que explicitem interação) e envolvimento do falante com o assunto (pelo uso de vocabulário expressivo, redundâncias e exageros do falante, introdução do presente histórico, uso do discurso direto e emprego de partículas adverbiais modalizadoras). Todos esses recursos indicam a presença da interatividade. 
Para exemplificar tal aspecto, selecionamos trechos do texto "Gosto não se discute, pesquisa-se", publicado na Carta Capital em 18 de fevereiro, lembrando que o recurso também é freqüente na Claudia Cozinha. A crônica trata das pesquisas realizadas antes do lançamento de novos produtos. Vejamos alguns exemplos de como os três diferentes tipos de envolvimento surgem e deixam explícito o uso de recursos de interatividade (os grifos são nossos):

\begin{tabular}{|c|c|}
\hline \multicolumn{2}{|l|}{ Auto-envolvimento } \\
\hline $\begin{array}{l}\text { Pronomes e verbos em } 1^{\mathrm{a}} \\
\text { pessoa } \\
\text { Processo mental }\end{array}$ & $\begin{array}{l}\text { Além de Jesus, arrisco dizer que, hoje, só a pesquisa salva. } \\
\text { Afirmo, e creio que não erro, que muitos restaurantes poderiam } \\
\text { melhorar de maneira assustadora se decidissem fazer uma } \\
\text { pesquisa. }\end{array}$ \\
\hline \multicolumn{2}{|l|}{ Envolvimento falante/ouvinte } \\
\hline $\begin{array}{l}\text { Pronomes e verbos em } 2^{\mathrm{a}} \\
\text { pessoa }\end{array}$ & $\begin{array}{l}\text { Não sei se você já se deu conta de que tudo na vida melhorou de } \\
\text { maneira espetacular. }\end{array}$ \\
\hline $\begin{array}{l}\text { Simulação de diálogo direto } \\
\text { com o leitor }\end{array}$ & $\begin{array}{l}\text { Vai me dizer que você acredita que o cozinheiro decide por um } \\
\text { novo produto e o coloca nas lojas? }\end{array}$ \\
\hline Marcadores conversacionais & $\begin{array}{l}\text { Um supermercado é freqüentado exclusivamente por gourmets, } \\
\text { por críticos, por profundos conhecedores das artes culinárias? } \\
\text { Qual o quê! }\end{array}$ \\
\hline \multicolumn{2}{|l|}{ Envolvimento falante/assunto } \\
\hline Exageros e redundâncias & $\begin{array}{l}\begin{array}{l}\text { Ele é seu predileto, mesmo que não seja. Você adora aquele } \\
\text { produto, mesmo detestando-o. }\end{array} \\
\text { A pesquisa é um instrumento que tem bases científicas sólidas e } \\
\text { irrefutáveis. }\end{array}$ \\
\hline Discurso direto & $\begin{array}{l}\text { E se você, fascinado com a vida, não teve tempo ainda de parar } \\
\text { e pensar “por que e como tudo ficou tão melhor?”, vou lhe } \\
\text { explicar. }\end{array}$ \\
\hline
\end{tabular}

Depois de tratar dos aspectos comuns às crônicas das duas revistas, passemos às estratégias individuais. $\mathrm{Na}$ Claudia Cozinha, é comum a intertextualidade, que ocorre quando os textos apresentam indícios da voz do outro em seu interior. Para entender de que forma a voz do outro entra no discurso, devemos remeter à noção de intertextualidade cunhada por Kristeva (1974), segundo a qual todo enunciado é inerentemente intertextual. Em outras palavras, a autora se 
baseou na teoria do dialogismo de Bakhtin para frisar que todo texto é permeado por outros, de forma implícita ou explícita. O fato de ser orientado para alguém - seja o interlocutor ou um leitor imaginário - é também constitutivo da dialogicidade de todos os discursos, aspecto diretamente ligado à interatividade:

Toda palavra comporta duas faces. Ela é determinada tanto pelo fato de que procede de alguém, como pelo fato de que se dirige para alguém. Ela constitui justamente o produto da interação do locutor e do ouvinte. Toda palavra serve de expressão a um em relação ao outro (Bakhtin, 1995[1929]:113).

Chama-se intertextualidade a aplicação da teoria do dialogismo ao campo da Teoria Literária, especialmente em virtude dos já citados estudos de Kristeva. Para a autora, qualquer texto é construído como um mosaico de citações, mesmo que o autor não saiba disso:

Todo texto se constrói como um mosaico de citações, todo texto é absorção e transformação de um outro texto. Em lugar da noção de intersubjetividade, instala-se a de intertextualidade e a linguagem poética lê-se pelo menos como dupla (Kristeva, 1974:63-64).

Para observar uma manifestação da intertextualidade no texto jornalístico sobre gastronomia, partimos da análise de trecho do texto "Toda comida é afrodisíaca”, da Claudia Cozinha do bimestre de janeiro/fevereiro. É a história de uma personagem que chama para o primeiro encontro, em sua casa, um pretendente que havia conhecido apenas por carta ou telefone. Ao ver que o rapaz não tem nenhum atrativo físico, planeja encontrar uma maneira de fazê-lo ir embora o quanto antes - até que ele entra na cozinha e revela seus dotes culinários:

Os cheiros invadindo a casa toda, a boca salivando, a amiga viu o sátiro se transmutar em belo herói, e ela já o queria com todas as suas forças e feromônios.

A autora afirma que o personagem se transmutou de sátiro em herói, remetendo a figuras tradicionais da mitologia grega: enquanto o sátiro era tido como uma assustadora divindade de pés de cabra e chifres que habitava os bosques, o herói tinha como representante principal a figura de Hércules - filho do deus Juno com a mortal Alcmena, cumpriu todos os chamados Doze Trabalhos de Hércules, incluindo matar um leão com as próprias mãos e vencer o gigante Anteu (Bulfinch, 1999). Ou seja, de um ser de aparência bizarra, tornou-se o responsável por "salvar" a moça com todas as honrarias. 
A Carta Capital, por sua vez, destaca-se pelo uso constante da ironia, um tipo particular de humor em que o enunciador se volta contra a própria enunciação. Tal recurso exige conhecimento prévio de dois discursos distintos para compreensão, uma vez que a ambigüidade essencial do discurso irônico está em aceitar simultaneamente seus sentidos literal e figurado. Dois discursos fazem parte da composição irônica e cabe à memória discursiva do receptor fazer a ligação entre a significação dita literal e a significação irônica pretendida pelo locutor: diferentemente da mentira, em que a simulação pretende se passar por verdade, o engano irônico se oferece para que o receptor o adivinhe ou perceba como engano (Brait, 1996:81). É importante destacar que a ironia é uma estratégia poderosa de argumentação e que o discurso irônico é propositalmente ambivalente.

Apresentamos um trecho do texto "A macrô e a deprê", da Carta Capital, em 11 de fevereiro, no qual o narrador visita uma médica macrobiota e se surpreende com suas avaliações sobre sua saúde:

Busquei na memória e acredito - não juro - que devo ter lido em algum momento de minha vida alguns relatos de portadores dos mais hediondos cânceres que se arrependiam profundamente por ter comido arroz integral que ficara na panela por 43,45 e até por 50 minutos.

Trata-se de uma resposta à médica macrobiota, que afirmou que o arroz integral deve ser cozido durante cronometrados 40 minutos. $\mathrm{O}$ autor ironiza sobre as possíveis conseqüências de deixar o grão cozinhando durante mais tempo, incluindo doenças diversas. A ironia está justamente na improbabilidade de o arroz causá-las e na falta de racionalidade da exigência da médica.

Por fim, é importante perceber como se comporta a titulação nas crônicas do corpus. Frisamos que falar de titulação é adentrar um tema ainda pouco explorado nos estudos do texto jornalístico. Não encontramos material específico sobre titulação de críticas, crônicas ou de outros gêneros próprios do jornalismo opinativo, mas ainda assim optamos por abordar essa questão, por haver observado que os títulos apresentam características interessantes a nossa análise.

Ao tratar da estrutura da notícia na imprensa, van Dijk (1996) chama de sumário a seção que engloba a manchete e o lide. Juntos, tais elementos formam uma espécie de resumo da notícia. Para o autor, a estrutura temática e o esquema da 
notícia ajudam o processo cognitivo de organização da informação na memória, assim como seu uso e posterior recordação. Os conhecimentos prévios do leitor são requisitados na hora da interpretação da informação. Enquanto os títulos de matérias e reportagens primam pela objetividade, os títulos de críticas e crônicas, assim como de outros gêneros do jornalismo opinativo, não se encaixam em regras fixas e podem fazer uso de recursos variados para chamar a atenção do leitor.

De fato, a titulação das crônicas da Claudia Cozinha e da Carta Capital apresentou grande diversidade de estratégias. Na primeira, temos títulos como "Comida de cachorro" (humor) e "Simplifique a vida", de setembro/outubro (interatividade). Na segunda, há exemplos como "Gosto não se discute, pesquisa-se" (trocadilho), de 18 de fevereiro, "É melhor a gente dar um tempo" (coloquialidade), de 4 de fevereiro, "Prescrevo uma sugestão" (interatividade), de 16 de junho, e "Humildade, ainda que tarde" (intertextualidade, em uma referência aos dizeres da bandeira mineira "Liberdade ainda que tarde"), de 25 de fevereiro. Tais recursos são utilizados para seduzir e envolver o leitor.

\section{A crítica no jornalismo gastronômico}

Ao contrário do que aconteceu na análise das crônicas, na observação das críticas não encontramos aspectos comuns às seções "Mundo Gourmet", da Folha de S.Paulo, e "Gula Indica Restaurantes”, da Gula. Ao contrário, as críticas dos dois veículos apresentam fortes distinções: enquanto o jornal prima pelo uso da ironia e da narrativa (especialmente como um recurso de contextualização dos restaurantes), na revista os recursos da interatividade e da metáfora sobressaem.

Acreditamos que tais diferenças não ocorrem por acaso: o público-alvo da Gula é o gourmet, enquanto a Folha de S.Paulo é voltada para uma audiência bem mais ampla - assim, cabe ao crítico apresentar em que contexto os restaurantes se inserem por meio da narrativa. A Gula, por supor que o seu leitor tem conhecimentos sobre gastronomia, dispensa explicações detalhadas sobre pratos e restaurantes, dialogando com o leitor de igual para igual.

Consideramos essencial, assim, oferecer um breve histórico das duas publicações. De acordo com o Novo Manual da Redação (1992), a Folha nasceu em 1921sob o nome Folha da Noite. Quatro anos depois, surgiu o vespertino Folha da 
Manhã. Em 1931, ambos foram comprados por três empresários. A empresa adquiriu seu nome atual - Folha da Manhã S/A - em 1945. Aos dois jornais anteriores, juntou-se a Folha da Tarde, em 1949. O caderno cultural Ilustrada, onde hoje se encontra a seção de gastronomia, começou a circular em 1958 (Folha Online, s.d.). Os três jornais se fundiram na atual Folha de S.Paulo em 1960. Foi apenas na década de 1980, no entanto, que a Folha de S.Paulo se tornou o diário de maior circulação no país.

A seção que analisamos traz críticas de restaurantes, que mesclam a objetividade da descrição das casas e a subjetividade da opinião sobre o local e os pratos. Ao final, todos os textos trazem uma "ficha técnica" com cotação de preços (expressa em cifrões, que podem variar de um a quatro), avaliação (expressa em estrelas - ou falta delas - para expressar ruim, regular, bom, ótimo e excelente), endereço, telefone, horário de funcionamento e faixa de preços das entradas, pratos principais e sobremesas, com os valores dos itens mais baratos e mais caros do menu em cada uma das três seções.

A revista Gula, por sua vez, é especializada em alimentação, mas tem um perfil diametralmente oposto ao da Claudia Cozinha. O público leitor não parece ser composto por donas de casa, mas por pessoas que gostam de cozinhar e fazem isso por hobby, não por obrigação. Criada em junho de 1992 e considerada a revista mais importante do país sobre o assunto, a Gula traz uma seção especializada em críticas de estabelecimentos: a "Gula Indica”, que se subdivide em Restaurantes, Miscelânea (sobre especialidades), Agenda e Bar. Rio de Janeiro e São Paulo são as cidades mais comumente avaliadas, mas há exceções. Alguns preciosismos são adotados, como o uso de termos nas suas línguas de origem (aqui o plural de pizza não é "pizzas", mas “pizze”, por exemplo). De um modo geral, o léxico é específico e costuma dispensar explicações, uma vez que está subentendido que o leitor da revista já está habituado ao tema da gastronomia e ao seu vocabulário usual.

Como é comum nas críticas, há uma ficha técnica com informações sobre o local: nome, endereço, telefone, comida, ambiente (desmembrado nos itens decoração e conforto em agosto de 2004), ruído (introduzido no mesmo mês), carta de vinhos, bar, horário, preço, cartão de crédito e valor do manobrista. Tudo é descrito com adjetivos, item por item. O preço varia de um a cinco cifrões, segundo o 
gasto médio de uma pessoa em refeição com couvert, prato principal e sobremesa, sem bebida.

Iniciemos nossa análise pela Folha. A ironia é freqüente na seção "Mundo Gourmet”, como podemos ver na crítica publicada em 15 de janeiro:

A febre da cozinha japonesa na cidade não acaba nunca. A tal ponto que nem sequer é preciso ter japoneses (ou seus descendentes) nos seus restaurantes... O Sassá Sushi, aberto em setembro no Itaim Bibi, é um exemplo. Nasceu de uma escola de culinária japonesa montada pelo engenheiro Alexandre Saber (o Sassá), de 31 anos. A escola agora funciona dentro do restaurante, que ele montou com o amigo e ex-aluno Juliano Valese, 26, que também já dava aulas na escola. Nenhum deles remotamente japonês, como se vê. (...) A impressão é reforçada pela presença, no cardápio, de boa oferta de sushis adolescentes (como chamo aqueles enrolados cheios de ingredientes de influência americana e nomes engraçadinhos), e pelo sistema de rodízio que vigora à noite (junto com o serviço à la carte).

O restaurante é japonês, mas nenhum de seus donos é "remotamente japonês, como se vê”. Ou seja, a casa quer parecer ser algo que não é de fato. O tom irônico se completa com o comentário sobre os sushis adolescentes, "aqueles enrolados cheios de ingredientes de influência americana e nomes engraçadinhos”, isto é, com receitas bem diversas das encontradas nos restaurantes japoneses tradicionais.

A narrativa marca presença na seção, em geral como uma maneira de contextualizar o restaurante no cenário paulistano, como podemos observar no texto “Costela 30 Horas traz a São Paulo a fartura do interior”, de 10 de junho, sobre um restaurante de Sorocaba que acaba de se instalar na capital:

O proprietário é o mesmo: Osmar Migliorini, que há 15 anos abriu sua primeira casa e lá dissemina a fama da costela lentamente assada. A idéia de vir para São Paulo foi lançada por um cliente que há 11 anos freqüentava sua casa, o arquiteto Marcos Cardoso, agora seu sócio na capital.

Consideramos que tal recurso tem função primordialmente didática: por se tratar de um jornal de grande circulação, convém esclarecer para o leitor - que pode ser iniciado no circuito gastronômico da cidade ou não - de onde surgiu aquele restaurante. Em outros casos observados, a narrativa serve para contar como veio um prato, por exemplo. 
Lembramos aqui que o autor usa o espaço no jornal não apenas para criticar um determinado restaurante, mas também para apresentar ao leitor questões mais amplas ligadas ao setor da gastronomia. Em outro texto, o autor dedica mais que a metade do espaço a uma discussão sobre as vantagens e desvantagens do sistema de atendimento self-service. Além de servirem como introdução às críticas dos restaurantes, trechos como esse cumprem a função de debater temas diversos relacionados à gastronomia, fazendo o leitor pensar sobre o assunto e, ao mesmo tempo, envolvendo-o para ler o restante do texto.

Passemos à análise da revista Gula, onde se destacam a interatividade e as metáforas. Exemplifiquemos a primeira característica na crítica "Jantar quase secreto", publicada em fevereiro:

Se você é do tipo que adora descobrir cantinhos, tome nota. (...) O salmão marinado com endívias e pimenta-rosa e o peito de pato com mel e limão, que provei, corresponderam às expectativas - e olha que fiz contagem regressiva desde o dia em que liguei para reservar mesa. (...) Márcia prefere não divulgar o endereço e continuar acreditando na clientela que descobre o Chez Marcianita pelo boca-a-boca. Então, fica entre nós!

Como podemos notar, a interatividade aqui aparece em tom de diálogo íntimo com o leitor - como se o crítico fosse um amigo que estivesse fornecendo dicas preciosas de algo que não se deve perder. Narrativas breves como "O salmão marinado com endívias e pimenta-rosa e o peito de pato com mel e limão, que provei, corresponderam às expectativas - e olha que fiz contagem regressiva desde o dia em que liguei para reservar mesa”, com exploração de recursos como o uso da primeira pessoa do singular e da linguagem coloquial, indicam o clima de intimidade entre autor e leitor. A autora fornece dicas, no início do texto, e ainda pede segredo, no final, com o uso da expressão coloquial "Fica entre nós!", como se estivesse de fato dialogando com o leitor.

Outra forte presença nas crônicas da revista é a metáfora. Usamos aqui a definição de Lakoff e Johnson (1980), para quem as metáforas, em vez de serem meros recursos retóricos, permeiam a vida cotidiana e o modo de percepção humano, ajudando a definir a realidade do nosso entorno sem que nos demos conta. As metáforas - em que a relação entre o objeto designado e a palavra usada para designá-lo é de semelhança - não são, para esses autores, somente uma questão de 
linguagem, mas de estruturação de processos mentais. A metáfora, então, deixa de ser uma simples figura de linguagem e passa a ser uma maneira de conhecer o mundo - não de forma apenas lógica, mas primordialmente criativa. Marcuschi (1978) lembra que as expressões metafóricas acabam por suprir um campo que as palavras não conseguem abarcar apenas com seus significados ditos literais.

Expressões como por exemplo "a recepção foi fria" ou "o dia está triste" dizem muito mais do que se quiséssemos obter, com o mesmo efeito cognitivo, este conteúdo emotivo ou subjetivo através de descrições (literais) (Marcuschi, 1978: 9-10).

Apresentamos abaixo alguns exemplos de metáfora no texto "Bistrot na Granja”, publicado em agosto na Gula:

É triste imaginar um futuro sem a bucólica região da Granja Viana, no vizinho município de Cotia, um enclave de silêncio e verde na fronteira oeste da cidade. Infelizmente, o risco existe - já que tantos outros tesouros de nosso entorno sucumbiram frente ao incontrolável crescimento de São Paulo. Já temos razão suficiente, portanto, para, vez por outra, enfrentar os 13 quilômetros que nos separam do pequeno paraíso e revisitar a Granja com a alma de turista, leve e remoçada. O Felix Bistrot que ali funciona há sete anos insinua ares de renovação. (...) Nos bastidores, no entanto, a orquestra requer ainda peque-nos ajustes, para torná-la mais uniforme.

Verificamos a presença de certas metáforas que, de tão comuns, chegam a passar despercebidas pelo olhar do senso comum - é o caso de termos como "tesouros" e "paraíso". Vamos nos ater, no entanto, ao trecho que se refere à cozinha como bastidores e à equipe como orquestra. Metáforas desse tipo são comuns na revista. Podemos defender que se trata de um sinal que a Gula trata a cozinha como arte. A equipe deve funcionar em plena harmonia, como uma orquestra, sem falhas, para trazer dos bastidores, a cozinha, a obra de arte final, tratada como uma verdadeira estrela.

Aproveitamos ainda tal exemplo para ressaltar mais uma vez que os críticos da revista Gula lançam mão de adjetivação farta em suas descrições, ao contrário do que faz o crítico da Folha de S.Paulo, Josimar Melo, ao optar por imprimir maior objetividade aos seus textos. Acreditamos, assim, que haja uma política editorial na Gula que influencie no estilo das críticas, pois existe uniformidade estilística apesar 
de se tratar de uma equipe de autores e não de uma autoria única, como no caso do jornal.

Por fim, voltemos nossas atenções para a titulação das duas seções. Ao contrário do que acontece com as crônicas, observa-se aqui uma forte predominância de descrições objetivas. Percebemos que os títulos destacam assuntos como a comida, o local, o preço e o chef, sendo estes dois últimos menos freqüentes. Na Folha de S.Paulo, temos títulos como "Pinus oferece uma cozinha simples e bem pensada" (ênfase à comida), de 20 de maio, "Emilia Romagna tem filial tranqüila na Granja Viana" (ênfase ao local), de 11 de março, "MoriSushi traz resultado condizente com o preço" (ênfase ao preço), de 25 de março, e "Lola Bistrô traz amostra da nova geração de chefs" (ênfase ao chef), de 8 de janeiro. Na Gula, há exemplos como "Italiano encantador" (comida), em setembro, "Francês no Itaim" (local), em outubro, "Bom e barato” (preço), em outubro, e “Revelação de talento” (chef), em julho.

\section{Considerações finais}

Esperamos, com este trabalho, ter alcançado nosso objetivo de dar início às explorações do jornalismo gastronômico brasileiro e, ainda, a novos estudos sobre o jornalismo cultural. Para tanto, decidimos focar nosso estudo na crítica e na crônica de gastronomia.

As crônicas apresentaram duas características comuns aos veículos Claudia Cozinha e Carta Capital: a interatividade e a narrativa. O primeiro aspecto tenta uma aproximação com o leitor, enquanto o segundo representa o tipo textual ideal para contar as histórias tão típicas do gênero em questão.

$\mathrm{Na}$ seção de crônicas "Pé na Cozinha", da revista Claudia Cozinha, verificamos que a interatividade se assemelha a uma conversa com o leitor, o que gera uma sensação de intimidade que é reforçada pelo uso da narrativa em tom confessional. Essa construção de laços afetivos entre leitor e cronista casa com o perfil da revista, voltado para donas de casa às voltas com os desafios do cotidiano. Observamos ainda a presença da intertextualidade como mote para a cronista contar histórias ligadas ao cotidiano.

A seção "Refogado", da Carta Capital, por sua vez, tem como diferencial a ironia. Aqui, ela aparece como uma estratégia que permeia a narrativa e diversas 
vezes descamba em um tipo de moral da história, em que o autor deixa de lado esse recurso para fechar o texto com uma observação séria.

Em ambas as seções, as titulações das crônicas se mostraram ricas em expedientes como humor, duplo sentido, trocadilhos, coloquialidade, ironia, metáfora, intertextualidade e interatividade. Assim, mesmo antes de começar a ler o texto, o leitor se vê envolvido e estimulado a continuar a leitura.

De modo geral, podemos concluir que a crônica se caracteriza como um espaço da subjetividade, em que o narrador interage com o leitor e com ele busca dialogar. Essa conversa se dá no âmbito da cozinha como local de sociabilidade e convívio.

As críticas não apresentaram estratégias comuns aos dois veículos, exceto na titulação. Os títulos costumam ser descritivos, enfatizando objetivamente fatores como a comida ou o ambiente de determinado restaurante e deixando claro o que está por vir. Excetuando-se esse ponto, cada um dos veículos estudados segue caminhos lingüístico-discursivos bem distintos.

A ironia é marcante nos textos da coluna "Mundo Gourmet", do jornal Folha de S.Paulo. Também é recorrente o uso da narrativa, mas com função diversa daquela das crônicas: aqui, ela serve para contextualizar os novos restaurantes no cenário paulistano, indicando quem são seus donos e chefs e de onde vieram. Não há uso exacerbado de adjetivos na seção. O autor dá preferência a um estilo mais técnico e descritivo a fim de deixar as escolhas para o leitor.

Finalmente, na seção de críticas "Gula Indica Restaurantes", da revista Gula, a interatividade surge para que o crítico se aproxime do leitor, fornecendo dicas e sugestões de pratos, numa postura diversa da que apresenta o crítico da Folha de S.Paulo. Ao que parece, a idéia é tratar o leitor de igual para igual, pois supõe-se que se trata de alguém com algum conhecimento gastronômico. Um ponto interessante é o uso de metáforas ligadas à arte - como elenco (para pratos) e orquestra (para chefs). Será porque a revista prima pela defesa da gastronomia elevada ao status de arte?

Em relação às críticas, percebemos um predomínio do chamado jornalismo de serviço, em que o jornalista busca oferecer informações - de maneiras distintas 
em cada veículo, é certo - para que o leitor possa usufruir delas em sua vida. Cada uma das críticas vem acompanhada de uma ficha técnica com os dados de cada casa, para facilitar a tarefa do leitor.

Por fim, consideramos importante mencionar que temas tidos como "menores", como a gastronomia, acabam gerando grande curiosidade nos leitores e se tornando "maiores" e mais importantes, numa equação que envolve leitores, jornalistas, veículos de comunicação e anunciantes. Os meios de comunicação interferem na formação do público e este passa a demandar mais informação sobre o tema - daí a importância de os pesquisadores em Comunicação estarem atentos a fenômenos como esse.

\section{Referências bibliográficas}

BAKHTIN, M. 1995 [1929]. Marxismo e filosofia da linguagem. 6. ed., São Paulo, Hucitec, 196 p.

BRAIT, B. 1996. Ironia em perspectiva polifônica. Campinas, Editora da Unicamp, $266 \mathrm{p}$.

BULFINCH, T. 1999. O livro de ouro da mitologia: histórias de deuses e heróis. 8. ed., Rio de Janeiro, Ediouro, 417 p.

CHAFE, W. 1985. Linguistic differences produced by differences between speaking and writing. In: D. OLSON et al (eds.). Literacy, Language and Learning: The Nature and Consequences of Reading and Writing. Cambridge, Cambridge University Press, p. 105-123.

DIJK, T. A. 1996. Cognição, discurso e interação. 2. ed., São Paulo, Contexto, 208 p.

FOLHA ONLINE. Círculo Folha. Acessado em: 1 de novembro de 2005. Disponível em http://www1.folha.uol.com.br/folha/circulo/index.htm.

FRENCH, P. 2000. Introdução. In: P. KAEL. Criando Kane e outros ensaios. Rio de Janeiro, Record, p. 9-16.

GALENO, A. 2002. Palavras que tecem e livros que ensinam a dançar. In: G. CASTRO e A. GALENO (orgs.). Jornalismo e literatura: a sedução da palavra. São Paulo, Escrituras, p. 99-108.

GANCHO, C. V. 1997. Como analisar narrativas. São Paulo, Ática , 72 p. 
GOMES, I. M. 1994. O papel da avaliação na narrativa jornalística. Investigações, 4:169-188.

GUARACIABA, A. 1992. Crônica. In: J. M. MELO (org.). Gêneros jornalísticos na Folha de S.Paulo. São Paulo, FTD, p. 82-90.

KRISTEVA, J. 1974. Introdução à semanálise. São Paulo, Perspectiva , 177 p.

LAKOFF, G. e JOHNSON, M. 1980. Metaphors we live by. Chicago, The University of Chicago Press, $242 \mathrm{p}$.

MARCUSCHI, L. A. 1978. A propósito da metáfora. Recife, PE. Artigo (mimeo.). Universidade Federal de Pernambuco, $17 \mathrm{p}$. . 1999. Marcas de interatividade no processo de textualização na escrita. In: Seminário de Filologia e Língua Portuguesa, I, São Paulo, 1999. Anais do I Seminário de Filologia e Língua Portuguesa, São Paulo, Humanitas, 1:139156.

MELO, J. M. 2002. A crônica. In: G. CASTRO e A. GALENO (orgs.). Jornalismo e literatura: a sedução da palavra. São Paulo, Escrituras, p. 139-154. . 2003. Jornalismo opinativo: gêneros opinativos no jornalismo brasileiro. 3. ed. rev. e ampl.., Campos do Jordão, Mantiqueira , 238 p.

MENEZES, R. 2002. Relações entre a crônica, o romance e o jornalismo. In: G. CASTRO e A. GALENO (orgs.). Jornalismo e literatura: a sedução da palavra. São Paulo, Escrituras, p. 163-171.

NOVO MANUAL DA REDAÇÃO. 1992. 7. ed., São Paulo, Folha de S.Paulo, 331 p.

TANNEN, D. 1989. Talking voices: repetition, dialogue and imagery in conversational discourse. Cambridge, Cambridge University Press, 256 p.

\section{Referências complementares}

LABOV, W. e WALETZKY, J. 1967. Narrative analysis: oral versions of personal experience. In: J. HELM (ed.). Essays on the verbal and visual arts. Seattle, University of Washington Press, p. 12-44.

LABOV, W. 1972. Language in the inner city: studies in the black English vernacular. Philadelphia, University of Pennsylvania Press, $440 \mathrm{p}$. 